\title{
Peningkatan Pengetahuan Kader Posyandu dalam Pembuatan PMT Berbahan Dasar Kelor sebagai Upaya Percepatan Pencegahan Stunting
}

\author{
Maya Weka Santi ${ }^{1 *}$, Cherry Triwidiarto ${ }^{2}$, Theo Mahiseta Syahniar ${ }^{3}$, \\ Refa Firgiyanto $^{4}$, Mira Andriani ${ }^{5}$ \\ ${ }^{12345}$ Politeknik Negeri Jember \\ E-mail: mayaweka@polije.ac.id
}

\begin{tabular}{ll}
\hline Article History: & Abstrak: \\
Received: Juli & Berdasarkan data profil Dinas kesehatan Kota \\
Revised: Agustus & Probolinggo Tahun 2017 masih ditemukan \\
Accepted: September & balita mengalami gizi buruk sebanyak 27 balita. \\
Available & Kecamatan Kanigaran merupakan salah satu \\
online:Desember & Kecamatan di Kota Probolinggo yang memiliki \\
& jumlah balita gizi buruk tertinggi sebanyak 10 \\
& balita (37\%). Peran kader di Posyandu \\
Kata Kunci: & "Boegenville" belum optimal karena masih \\
balita, gizi buruk, & memiliki pengetahuan yang kurang terkait \\
pemberian makanan & stunting dan cara pencegahannya. Kader juga \\
tambahan & belum berperan aktif dalam pengolahan \\
& Pemberian Makanan Tambahan (PMT) balita. \\
& Salah satu bahan makanan lokal yang baik untuk \\
& PMT adalah daun kelor (Moringa Oleivera). \\
& Dengan demikian diperlukan peningkatan \\
& pengetahuan kader posyandu dalam pembuatan \\
& PMT berbahan dasar kelor sebagai upaya \\
& percepatan pencegahan stunting. Kegiatan \\
& dilakukan dengan memberikan materi meliputi \\
& pengertian stunting, penyebab balita stunting, \\
& cara mencegah stunting dan pengertian PMT. \\
& Kegiatan pelatihan pembuatan PMT berbahan \\
& dasar kelor juga dilakukan dengan \\
menghasilkan tiga produk antara lain puding \\
oreo coklat kelor, nugget ayam kelor dan \\
cookies emping kelor. Hasil evaluasi dilakukan \\
dengan memberikan pretest dan posttest dengan \\
indicator keberhasilan skor 70. Sebanyak 30\% \\
kader memiliki nilai diatas 70 pada pretest dan \\
\hline
\end{tabular}


terjadi peningkatan pengetahuan berdasarkan hasil posttest $100 \%$ kader memiliki nilai diatas 70. Perlu untuk merancang program lanjutan sebagai tindak lanjut dari kegiatan ini yaitu pelatihan kewirausahaan produk PMT bagi untuk mendukung ekonomi kader Posyandu.

\section{Pendahuluan}

Hasil Riset Kesehatan dasar (Riskesdas) tahun 2018 menunjukkan angka stunting balita di Indonesia mencapai 30,8\%. Berdasarkan WHO angka stunting $>30 \%$ termasuk kategori sangat tinggi. Selain itu target Rencana Pembangunan Jangka Menengah Nasional (RPJMN) yang harus dicapai pada akhir 2019 adalah sebesar 28\% (Kemenkes RI, 2018b), Dengan demikian target RPJMN masih belum terpenuhi. Stunting disebabkan oleh banyak faktor, dimana salah satunya adalah kekurangan asupan makanan bergizi. Hal ini dapat menimbulkan dampak pada tingkat kecerdasan anak, kerentanan terhadap penyakit, menurunnya produktivitas, serta dapat menghambat pertumbuhan ekonomi (Kemenkes RI, 2018a). Praktik pemberian makanan pada bayi dan balita seperti pemberian makanan pelengkap yang terbatas dalam jumlah, kualitas dan variasi kepada balita juga merupakan penyebab stunting (Gordon and Maule, 1989; Hall et al., 2018).

Balita merupakan salah satu kelompok yang rentan untuk mengalami masalah kekurangan gizi dan sering berkaitan dengan kurang energi protein dalam jangka waktu yang lama. Pemberian Makanan Tambahan dapat berupa jajanan sehat sehingga membantu pemenuhan kebutuhan gizi balita karena balita cenderung menyukai makanan yang manis (Permatasari, 2018). Selain itu berdasarkan penelitian di Malawi, pemberian makanan tambahan berupa Ready to Use Therapeutic Food (RUTF) dengan kandungan energi 175kkal/ $\mathrm{kgBB} /$ hari, protein $\mathrm{gr} / \mathrm{kgBB} /$ hari dapat memberikan kontribusi sebesar 75\% kebutuhan energi dan $80 \%$ kebutuhan protein dalam sehari (Michael et al., 2005; 'WHO Child Growth Standards', 2009). Hal ini juga didukung oleh hasil penelitian (Fitriyani and Mulyati, 2012) bahwa ada pengaruh Pemberian Makanan Tambahan Protein (PMT-P) terhadap status gizi. 
Profil Dinas Kesehatan Kota Probolinggo Tahun 2017 menunjukkan masih ditemukan balita mengalami gizi buruk sebanyak 27 balita. Kecamatan Kanigaran merupakan salah satu Kecamatan di Kota Probolinggo yang memiliki jumlah balita gizi buruk tertinggi sebanyak 10 balita (37\%). Posyandu "Boegenville" RW IV Kelurahan Sukoharjo, Kecamatan Kanigaran, Probolinggo melaksanakan kegiatan utama salah satunya adalah pemantauan gizi balita. Upaya peningkatan peran dan fungsi Posyandu bukan semata-mata tanggungjawab pemerintah saja, namun semua komponen yang ada di masyarakat, termasuk kader. Peran kader dalam penyelenggaraan Posyandu sangat besar karena sebagai pemberi informasi kesehatan kepada masyarakat (Kesehatan, 2012).

Posyandu "Boegenville" terletak di Kelurahan Sukoharjo, kecamatan Kanigaran, Probolinggo, mulai didirikan pada tahun 1985. Hingga saat ini, Posyandu "Boegenville" menempati pekarangan rumah ibu Winarti ketua RT 2 RW IV, Kelurahan Sukoharjo, Kecamatan Kanigaran, Probolinggo. Kader Posyandu "Boegenville" adalah ibu-ibu anggota PKK. Latar belakang kader Posyandu "Boegenville" rata-rata tamatan Sekolah Menengah Atas (SMA). Kader masih memiliki pengetahuan yang kurang terkait stunting dan cara pencegahannya. Hal ini dibuktikan bahwa setiap dilakukan kegiatan Posyandu, selalu dilakukan pengukuran antropometri tubuh balita. Namun dalam pembuatan PMT selama ini Posyandu "Boegenville" belum dilakukan secara rutin karena keterbatasan sumber daya yang dimilikinya (baik biaya maupun sumber daya manusia).

Salah satu bahan makanan lokal yang baik untuk PMT adalah daun kelor (Moringa Oleivera) (Permatasari, 2018). Daun kelor merupakan bahan makanan dengan nilai gizi tinggi terutama zat besi. Zat besi dalam 100 gram daun kelor yaitu $7 \mathrm{mg}$, apabila ditepungkan menjadi 28,2 mg. Kadar protein dan zat besi pada makanan olahan kelor dapat memenuhi standar PMT balita (Sari and Adi, 2017). Selain itu, WHO menganjurkan agar anak-anak dan balita mengonsumsi daun kelor karena berkhasiat untuk meningkatkan kekebalan tubuh dan mencegah gizi buruk. Oleh sebab itu tim pengabdian masyarakat melakukan kegiatan peningkatan pengetahuan kader Posyandu dalam pembuatan PMT berbahan dasar kelor sebagai upaya percepatan 
pencegahan stunting di Kelurahan Sukoharjo, Kota Probolinggo.

\section{Metode}

Dalam rangka meningkatkan pengetahuan kader Posyandu dalam pembuatan PMT berbahan dasar kelor sebagai upaya percepatan pencegahan stunting maka langkah-langkah sistematis yang dilakukan adalah 1) Peningkatan pengetahuan melalui penyampaian materi tentang stunting dan cara pencegahannya; 2) Praktek membuat PMT (Pemberian Makanan Tambahan) berbahan dasar kelor dengan jenis makanan puding oreo coklat kelor, nugget ayam kelor dan cookies emping kelor; 3) Tanya jawab dan diskusi terkait materi yang telah disampaikan; 4) Pemberian pretest dan posttest sebagai upaya evaluasi kegiatan. Indikator keberhasilan tingkat pemahaman peserta pada program ini adalah $70 \%$ dari materi yang diberikan setelah dilakukan evaluasi menggunakan pretest dan posttest.

\section{Hasil}

a. Perijinan dan Sosialisasi Kegiatan

Sebelum dilakukan kegiatan pengabdidan kepada masyarakat, kegiatan diawali dengan melakukan perijinan dan sosialisasi kegiatan kepada salah satu pengurus Posyandu Boegenville. Kegiatan ini disambut dengan antusias oleh pengurus Posyandu Boegenville.

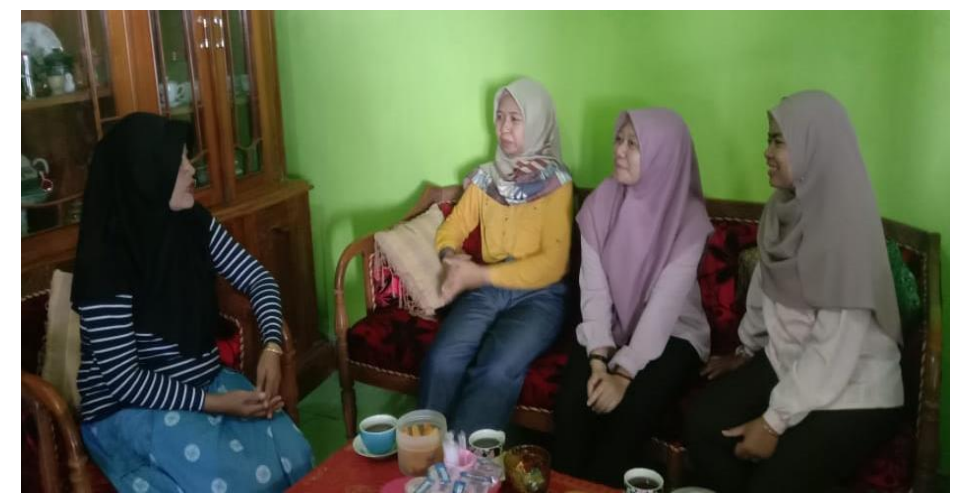

Gambar 1. Perijinan dan Sosialisasi Kegiatan kepada Salah Satu Penanggung Jawab Posyandu Boegenville

b. Peningkatan Pengetahuan Kader Posyandu tentang Stunting 
Di dalam kegiatan ini materi yang disampaikan meliputi pengertian stunting, penyebab balita stunting, cara mencegah stunting dan pengertian PMT (Pemberian Makanan Tambahan). Stunting merupakan suatu keadaan balita yang memiliki panjang atau tinggi badan yang kurang jika dibandingkan dengan umurnya. Anak balita dikatakan pendek apabila nilai Z-scorenya kurang dari -2SD (standar deviasi) dan sangat pendek apabila kurang dari 3SD (Kementerian Kesehatan, 2018). Faktor-faktor yang menjadi penyebab utama stunting antara lain ketidakseimbangan asupan makanan yang diberikan (hal ini berhubungan dengan kandungan zat gizi yang terdapat dalam makanan seperti protein, karbohidrat, mineral, lemak, vitamin, dan air), riwayat penyakit dan/ atau berat badan lahir rendah (BBLR), praktek pengasuhan balita yang tidak baik yang disebabkan kurangnya pengetahuan ibu mengenai kesehatan dan gizi sebelum dan pada masa kehamilan, setelah melahirkan, pemberian Air Susu Ibu (ASI) ekslusif, serta tidak adanya pemberian Makanan Pendamping Air Susu Ibu (MP-ASI). Pemberian materi pelatihan diberikan oleh salah satu tim pengabdian masyarakat, bidan dan petugas promosi kesehatan yang biasanya memberikan penyuluhan di Posyandu Boegenville.

\section{c. Pelatihan Pembuatan PMT Berbahan Dasar Kelor}

Pada pelatihan pembuatan PMT berbahan dasar kelor ini dibuat tiga produk antara lain puding oreo coklat kelor, nugget ayam kelor dan cookies emping kelor.

Bahan-bahan yang dibutuhkan untuk membuat puding oreo coklat kelor antara lain Bahan A: agar - agar plain 1 sachet; bubuk daun kelor 10gr; gula pasir $125 \mathrm{gr}$; air bersih $600 \mathrm{ml}$. Bahan B: agar - agar plain 1 sachet; gula pasir 115gr; susu kental manis 100gr; susu bubuk 50gr; oreo 14 keping (1/2 bungkus), cincang; air bersih $600 \mathrm{ml}$. Bahan C: agar-agar coklat 1 sachet; dark cooking chocolate (coklat blok) 50gr; gula pasir 100gr; air bersih 500ml.

Cara membuat puding oreo coklat kelor yaitu campur semua bahan A jadi satu lalu tambahkan air sedikit demi sedikit dan aduk sampai tercampur rata, lalu masak hingga mendidih tuang ke wadah (cetakan) diamkan \pm 10 menit (sampai agak mengeras). Lanjut campur bahan B kecuali oreo lalu 
tambahkan air sedikit demi sedikit dan aduk sampai tercampur rata, lalu masak hingga mendidih angkat campurkan orea yg sudah hancur, tuang di atas bahan A yg sudah mulai mengeras agar tidak tercampur saat menuang pelan-pelan dengan sendok sayur, diamkan \pm 10 menit/sedikit keras. Campur bahan $\mathrm{C}$ tambahkan air sedikit demi sedikit dan aduk sampai tercampur rata, masak hingga mendidih tuang ke atas bahan B apabila sudah keras. Diamkan \pm 15 menit taruh dalam kulkas sajikan dingin-dingin.

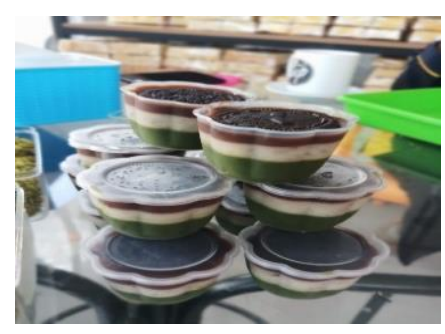

Gambar 2. Puding Oreo Coklat Kelor

Bahan-bahan yang dibutuhkan untuk membuat nugget ayam kelor adalah Adonan Nugget: daging ayam fillet tanpa tulang 200gr; daun kelor 50 gr (di blanching/ dikukus \pm 5 menit; tepung terigu 50gr; tepung maizena 50gr; telur ayam 1 butir; bawang putih 2 siung; bawang merah 2 siung; lada / merica halus 1gr; garam 3gr; gula pasir 5gr; kaldu jamur 1/2 sachet. Adonan pelapis: tepung terigu 90gr; tepung maizena 60gr; tepung beras 65gr; baking powder 10gr; lada / merica halus 5gr; garam 7-5gr; air 250ml; tepung panir secukupnya.

Cara membuat nugget ayam kelor adalah Blanching (kukus) terlebih dahulu daun kelor selama kurang lebih 5 menit. Langsung masukkan air dingin (air es) agar daun kelor tidak terlalu matang. Kemudian blender daun kelor hingga halus. Pisahkan daging ayam dari tulang dan kulit (di fillet), kemudian daging ayam potong kecil-kecil. Masukkan kedalam chopper (penggiling daging): daging ayam fillet beserta 1 butir telur, terigu, maizena, garam, gula pasir, lada halus, kaldu jamur, bawang putih, bawang merah dan daun kelor. Giling hingga daging ayam hancur dan adonan menjadi kalis (tercampur rata). Jika tidak memiliki chopper, bisa dicincang atau digiling menggunakan blender. 
Siapkan pinggan tahan panas (Loyang), olesi dengan minyak goreng atau alasi dengan plastik. Siapkan juga panci kukusan. Masukkan adonan dalam pinggan (Loyang). Kukus hingga matang. Kira-kira 30 menit. Keluarkan adonan dan biarkan hingga dingin. Jika sudah dingin, potongpotong sesuai selera. Buat adonan pelapis dengan mencampur semua bahan kecuali tepung panir. Gulingkan potongan nugget kedalam adonan pelapis yang sudah dibuat. Lalu gulingkan dalam tepung panir. Simpan sesaat dalam freezer. Hal ini bermanfaat supaya tepung panir lebih menempel kuat pada adonan. Jika ingin menghidangkan, goreng adonan dalam minyak panas dan banyak dengan api kecil.

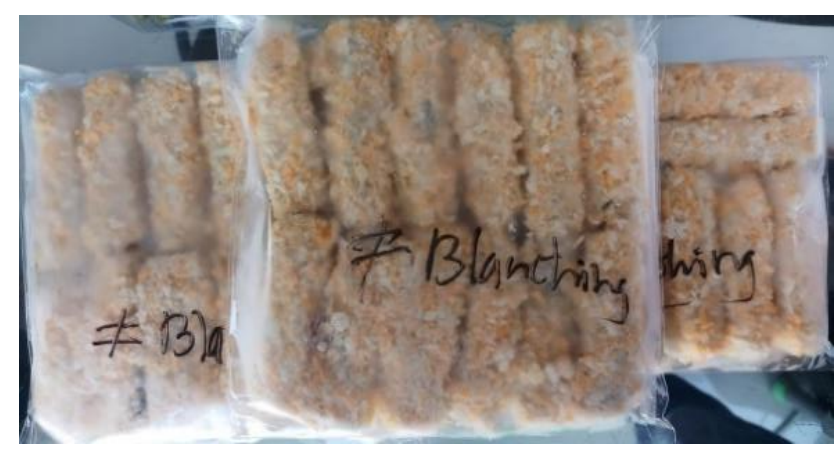

Gambar 3. Nugget Ayam Kelor

Bahan-bahan yang dibutuhkan untuk membuat cookies emping kelor adalah Tepung protein rendah, ayak 240gr; Bubuk Daun kelor 20gr; Emping mlinjo 75gr ditumbuk kasar; Butter 100gr; Margarin 70gr; Gula halus 130gr; Kuning telur 2 butir; Garam halus 1/4 sdt (2 gr); Susu kental manis 50 gr.

Cara membuat cookies emping kelor adalah siapkan wadah. Masukan butter, margarine dan gula halus. Aduk menggunakan mixer sampai tercampur rata. Kemudian, masukan kuning telur, susu kental manis dan garam, aduk hingga rata. Tambahkan bubuk daun kelor yang sudah diayak, aduk rata. Tuang terigu sedikit demi sedikit sambil diaduk. Tambahkan emping mlinjo aduk hingga rata. Siapkan Loyang (alasi dengan kertas baking) atau oles dengan margarine. Bentuk bulat bulat. Pipihkan menggunakan garpu supaya ada motif. Panaskan oven. Setelah adonan siap,masukan ke dalam oven, panggang dengan api kecil saja. Harus sering di cek agar cookies tidak gosong. 
Tempatkan ditoples atau wadah apabila cookies sudah benar benar dingin.

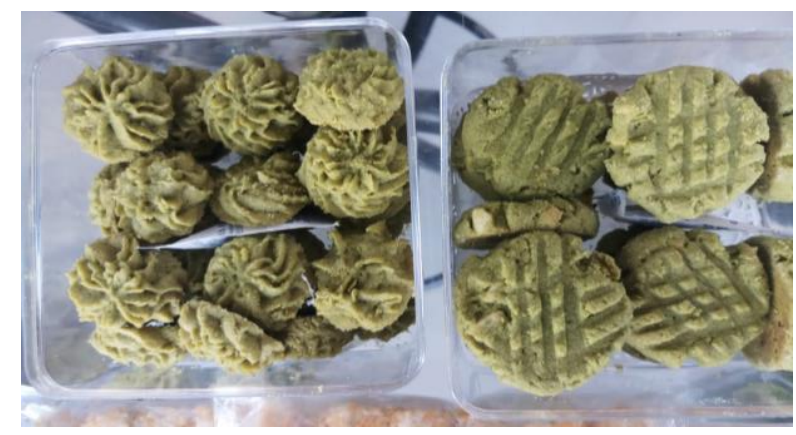

Gambar 4. Cookies Emping Kelor

Bahan-bahan yang dibutuhkan untuk membuat cookies emping kelor adalah Tepung protein rendah, ayak 240gr; Bubuk Daun kelor 20gr; Emping mlinjo 75gr ditumbuk kasar; Butter 100gr; Margarin 70gr; Gula halus 130gr; Kuning telur 2 butir; Garam halus 1/4 sdt (2 gr); Susu kental manis 50 gr

Cara membuat cookies emping kelor yaitu Siapkan wadah. Masukan butter, margarine dan gula halus. Aduk menggunakan mixer sampai tercampur rata. Masukan kuning telur, susu kental manis dan garam, aduk hingga rata. Kemudian tambahkan bubuk daun kelor yang sudah diayak, aduk rata. Tuang terigu sedikit demi sedikit sambil diaduk. Tambahkan emping mlinjo aduk hingga rata. Siapkan Loyang (alasi dengan kertas baking) atau oles dengan margarine. Bentuk bulat bulat. Pipihkan menggunakan garpu supaya ada motif. Panaskan oven. Setelah adonan siap,masukan ke dalam oven, panggang dengan api kecil saja. Harus sering di cek agar cookies tidak gosong. Tempatkan ditoples atau wadah apabila cookies sudah benar benar dingin.
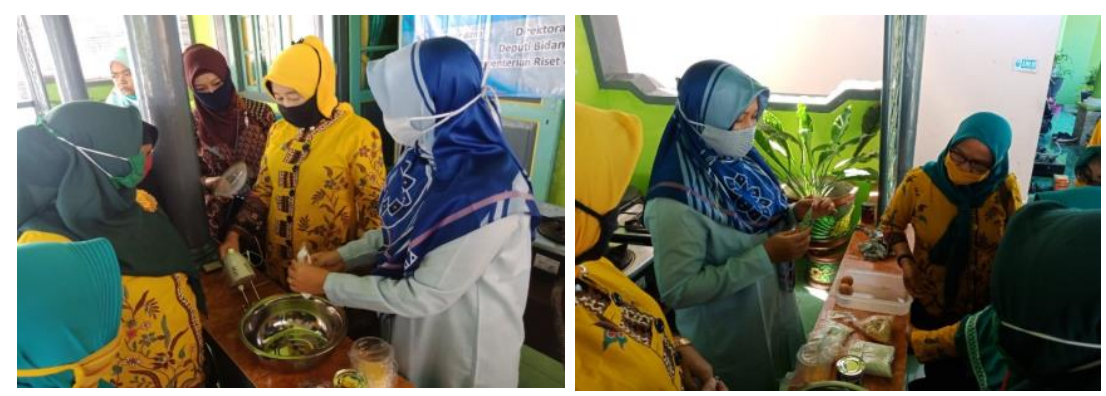

Gambar 5. Pelatihan Pembuatan PMT Berbahan Dasar Kelor 


\section{Diskusi}

Indikator keberhasilan tingkat pemahaman kader pada kegiatan pengabdian masyarakat ini dilihat dari hasil pretest dan posttest yang diisi oleh kader Posyandu Boegenville. Terdapat lima pertanyaan essay yang harus dijawab oleh kader Posyandu Boegenville. Total nilai dari 5 soal tersebut adalah 100 poin. Masing-masing pertanyaan memiliki nilai maksimal 20 poin jika benar, dan jika salah atau hampir benar memiliki nilai 0-15 poin pada masing-masing pertanyaan. Indikator keberhasilan tingkat pemahaman peserta pada program ini adalah $70 \%$ dari materi (nilai 70 ). Hasil penilaian pretest dan posttest kegiatan peningkatan pengetahuan kader Posyandu dalam pembuatan PMT berbahan dasar kelor sebagai upaya percepatan pencegahan stunting adalah sebagai berikut:

Tabel 1. Skor Pretest dan Posttest Peningkatan Pengetahuan Kader tentang Stunting

\begin{tabular}{ccccc}
\hline Kader & Nilai pretest & Keterangan & Nilai posttest & Keterangan \\
\hline A & 70 & $\mathrm{~L}$ & 90 & $\mathrm{~L}$ \\
\hline $\mathrm{B}$ & 35 & $\mathrm{TL}$ & 100 & $\mathrm{~L}$ \\
\hline $\mathrm{C}$ & 45 & $\mathrm{TL}$ & 70 & $\mathrm{~L}$ \\
\hline $\mathrm{D}$ & 80 & $\mathrm{~L}$ & 80 & $\mathrm{~L}$ \\
\hline $\mathrm{E}$ & 65 & $\mathrm{TL}$ & 90 & $\mathrm{~L}$ \\
\hline $\mathrm{F}$ & 45 & $\mathrm{TL}$ & 75 & $\mathrm{~L}$ \\
\hline $\mathrm{G}$ & 60 & $\mathrm{TL}$ & 90 & $\mathrm{~L}$ \\
\hline $\mathrm{H}$ & 60 & $\mathrm{TL}$ & 80 & $\mathrm{~L}$ \\
\hline $\mathrm{I}$ & 70 & $\mathrm{~L}$ & 80 & $\mathrm{~L}$ \\
\hline $\mathrm{J}$ & 50 & $\mathrm{TL}$ & 100 & $\mathrm{~L}$ \\
\hline
\end{tabular}

Ket: $\mathrm{TL}=$ Tidak Lulus dan L = Lulus, Sumber: (Data Olahan, 2020)

Berdasarkan tabel 1 dapat dilihat bahwa sebelum diberikan materi pelatihan, sebanyak 70\% kader Posyandu Boegenville memiliki nilai dibawah 70. Dengan demikian sebagian besar kader belum memahami tentang pengertian stunting, penyebab balita, cara mencegah stunting dan pengertian PMT (Pemberian Makanan Tambahan). 
Hasil pretest menunjukkan pada komponen pertanyaan "Apa yang ibu ketahui tentang balita stunting?" sebagian besar kader menjawab stunting merupakan pertumbuhan tidak normal. Hal ini kurang tepat karena pengertian tentang stunting lebih dititik beratkan pada kondisi dimana balita memiliki panjang atau tinggi badan yang kurang jika dibandingkan dengan umur. Pada komponen pertanyaan "Apa saja yang bisa menyebabkan balita stunting?", sebagian besar kader menjawab karena kekurangan zat gizi. Hal ini sudah benar, namun masih kurang spesifik. Selain itu terdapat beberapa kader yang menjawab kurang tepat dimana stunting disebabkan oleh kekurangan yodium.

Pada pertanyaan "Bagaimana cara mencegah stunting?", sebagian besar kader sudah menjawab benar dengan memberi asupan gizi yang baik dari mulai hamil. Namun masih ada yang menjawab dengan menggunakan garam yodium. Hal ini masih kurang tepat karena stunting lebih berkaitan dengan kekurangan zat nutrisi protein. Selanjutnya pada pertanyaan "Apa yang ibu ketahui tentang PMT (Pemberian Makanan Tambahan)?”, sebagian besar kader memberikan jawaban yang kurang spesifik yaitu makanan yang bergizi, makanan selain ASI, buah, susu, sayur mayur. Padahal kata kunci dari PMT adalah pemberian makanan tambahan pada usia 6 bulan ke atas selain ASI. Pada pertanyaan terakhir yaitu "Apa ibu mengetahui bahwa daun kelor dapat digunakan sebagai bahan dasar pembuatan PMT?", Sebagian besar kader menjawab tahu tanpa menyebutkan jenis olahan PMT berbahan dasar kelor.

Hasil posttest menunjukkan bahwa 100\% kader Posyandu Boegenville telah memiliki nilai diatas 70. Hal ini menunjukkan bahwa terdapat peningkatan pengetahuan pada kader. Jawaban yang disampaikan oleh kader sebagian besar tepat, terutama setelah mempraktikkan langsung pengolahan PMT berbahan dasar kelor, pada kader menjawab pertanyaan telah mengetahui bahwa daun kelor dapat digunakan sebagai bahan dasar pembuatan PMT dengan menyebutkan jenis produk makanan seperti nugget, pudding dan cookies kelor. 


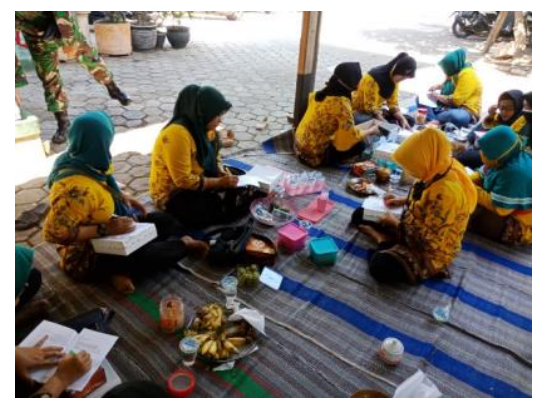

(a)

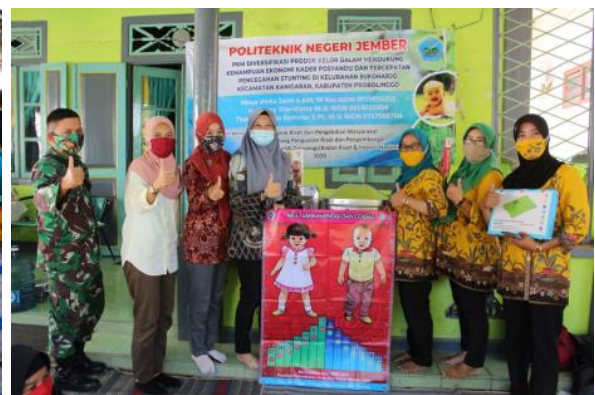

(b)

Gambar 6. a) Pengisian Pretest dan Posttest oleh Kader Posyandu Boegenville; Serah Terima Alat dari Tim Pengabdian Masyarakat kepada Kader Posyandu Boegenville

Setelah kegiatan peningkatan pengetahuan kader posyandu dalam pembuatan pmt berbahan dasar kelor sebagai upaya percepatan pencegahan stunting dilaksanakan, tim pengabdian masyarakat menyerahkan beberapa alat antara lain timbangan berat badan, microtoice, tikar stunting, oven, cooper, alat pengukus. Diharapkan alat tersebut dapat digunakan oleh kader Posyandu Boegenville dalam memberikan pelayanan kepada masyarakat khususnya balita di wilayah kerja Posyandu Boegenville seperti mengukur berat badan, mengukur tinggi badan, membuat PMT untuk balita dalam upaya percepatan pencegahan stunting pada balita.

\section{Kesimpulan}

Dalam setiap pelaksanaan kegiatan, diharapkan dapat berjalan dengan lancar sesuai rencana sehingga dapat bermanfaat bagi peserta kegiatan. Termasuk dalam kegiatan pemberian materi dan pelatihan pembuatan PMT berbahan dasar daun kelor kepada kader Posyandu Boegenville. Evaluasi yang dapat disampaikan berkenaan dengan pelaksanaan kegiatan ini adalah, mengingat tujuan yang ingin dicapai adalah tidak hanya memberi informasi, namun juga meningkatkan kemampuan kader Posyandu dalam membuat PMT untuk balita agar dapat membantu percepatan pencegahan stunting. Selain itu PMT hasil olahan berbahan dasar daun kelor dapat dikembangkan sebagai usaha rumah tangga demi menyokong ekonomi kader Posyandu Boegenville. 


\section{Pengakuan/Acknowledgements}

Ucapan terima kasih disampaikan kepada para kader Posyandu Boegenville RW IV Kelurahan Sukoharjo, Kecamatan Kanigaran, Probolinggo dan Direktorat Riset Pengabdian Masyarakat (DRPM) atas dukungan pendanaan sehingga kegiatan ini dapat terlaksana dengan baik; Dinas Kesehatan Kota Probolinggo dan Badan Kesatuan Bangsa dan Politik Kota Probolinggo atas bantuan perizinan. Kegiatan pengabdian sebagai salah satu upaya pemberdayaan masyarakat di sekitar Politeknik Negeri Jember dalam rangka penyelesaikan masalah yang sedang dihadapi oleh masyarakat. Selain itu, Politeknik Negeri Jember membuktikan dapat memanfaatkan ilmu pengetahuan secara benar demi kesejahteraan bersama.

\section{Daftar Referensi}

Fitriyani, F. and Mulyati, T. (2012). Pengaruh Pemberian Makanan Tambahan Pemulihan (PMT-P) terhadap Status Gizi Balita Gizi Buruk di Dinas Kesehatan Kota Semarang Tahun 2012. Journal of Nutrition College, 1, 371-381.

Gordon, J. R. and Maule, C. J. (1989). What's at stake., Canadian pharmaceutical journal, 122(2), 74-76, 78.

Hall, C. et al. (2018). Maternal Knowledge of Stunting in Rural Indonesia, International Journal of Child Health and Nutrition, 7(4), 139-145. doi: 10.6000/1929-4247.2018.07.04.2.

Kemenkes RI. (2018). Buletin Stunting, Kementerian Kesehatan RI, 301(5), $1163-1178$.

Kemenkes RI. (2018). Hasil Utama Riskesdas 2018.

Kesehatan, K. (2012). Ayo ke Posyandu, Transfusion Medicine and Hemotherapy. doi: 10.1159/000317898.

Michael, A. . et al. (2005). Comparison of Home-Based Therapy With ReadyTo-Use Therapeutic Food With Standard Therapy in The Treatment of Malnourished Malawian Children: A Controlled, Clinical Effectiveness Trial1-4, Am J Clin Nutr, 81, 864-870.

Permatasari, N. E. dan A. C. A. (2018). Daya Terima dan Kandungan Gizi

(Energi, Protein) Gyoza yang Disubstitusi Keong Sawah (Pilaampullacea) dan Puree Kelor (Moringa Oleifera), Daya Terima Kandungan Gizi, 62-70. doi: 10.20473/mgi.v13i1.62. 
Sari, Y. K. and Adi, A. C. (2017). Daya Terima, Kadar Protein dan Zat Besi Cookies Substitusi Tepung Daun Kelor dan Tepung Kecambah Kedelai, Media Gizi indonesia, 12(1), pp. 27-33.

WHO Child Growth Standards. (2009). Developmental Medicine \& Child Neurology, 51(12), 1002-1002. doi: 10.1111/j.1469-8749.2009.03503.x. 